\title{
EFFECT OF FARMYARD MANURE AND DIFFERENT SOURCES OF P AND K ON SOME MACRONUTRIENTS IN SOIL AND PLANT
}

\author{
B.Y. El-Koumey ${ }^{(1)}$, Fatma S. El-Shafei ${ }^{(1)}{ }^{\left({ }^{2}\right.}$ M.M. Shehata ${ }^{(1)}$ and \\ Samia S. Ekalawey ${ }^{(2)}$ \\ (1) Soil Sci., Dept., Fac. of Agric. Menoufia Univ. Egypt \\ (2) Soils, water and Environment research Institute, ARC, Giza, Egypt.
}

Received: Feb. 6, 2017

Accepted: May 8, 2017

\begin{abstract}
The pot experiments were performed at the Faculty of Agriculture, Minufiya University, Shibin El-Kom to investigate the effect of different sources and rates, of $P, K$ and organic manure on corn plants grown in both alluvial and calcareous soils. Two surface soil samples $(0-30 \mathrm{~cm})$ were collected from two locations. A) alluvial soil from experimental farm of the Faculty of Agriculture, Minufiya University, Shibin El-Kom. B) calcareous soil from Nubaria farm, Behera Governorate. Each polyethylene pot (15 cm diameter) was filled with $2 \mathrm{~kg}$ soils and planted with five grains of corn plant (Zea mays L.). After 14 days from planting the plants thinned to three plants per pot. The pots were irrigated to keep soil moisture at approximately $60 \%$ of the water holding capacity. The organic manure was added at 0,1 and $2 \%$. $P$ was added at $\left(0,15\right.$ and $\left.30 \mathrm{ppm}, \mathrm{P}_{2} \mathrm{O}_{5}\right)$ of superphosphate and Triplephosphate. The organic manure and phosphatic fertilizers were added before planting. Potassium was added at 0, 24 and $48 \mathrm{ppm} \mathrm{K}_{2} \mathrm{O}$ of potassium sulphate and potassium chloride.

After 45 days from planting the plants were harvested and dried at $70^{\circ} \mathrm{C}$, weighted, ground and digested for chemical analysis.

The application of FYM at rates of 1 and $2 \%$ to the both alluvial and calcareous soils caused a significant increase in dry matter yield of corn plants. The values of dry matter yield in alluvial soil, were higher than those obtained in the calcareous soil. The additions of FYM to both soils increased the N, P and $K$ uptake by corn plants. The application of FYM increased the availability of $P$ and $K$ in used soils. The application of phosphatic fertilizers increased the dry matter yield of corn plants grown in both. The dry matter yield of corn plants with triplephospate application was higher than those with superphosphate in alluvial soil, while the reverse was reverse was true in calcareous one. The $N, P$ and $K$ uptake by corn plants were obviously higher on alluvial soil than those on calcareous one with $P$ application. The application of phosphate fertilizers increased available $P$ and slightly increased available $K$ in used soils. Available $P$ and $K$ in alluvial soil were higher than those in calcareous one. Application of potassium sulphate was more effective in increasing dry matter yield of corn plants than potassium chloride in both soils. The absolute values of $N, P$ and $K$ uptake by corn plants by $\mathrm{K}_{2} \mathrm{SO}_{4}$ application were higher than those treated with $\mathrm{KCl}$-fertilizers. Application of potassium fertilizers increased the available $K$ in both used soils and slightly decreased availability $P$ in alluvial soil but there is no effect in calcareous soil.
\end{abstract}

Key words: FYM, Macronutrients, Corn Plant, Alluvial and Calcareous Soils.

\section{INTRODUCTION}

Organic fertilization deficiency limits the proctuction of many crops especially grain legumes in many soils. The application of farmyard manure to soil markedly increases plant growths availability of nutrients in soil and nutrients uptake by 0 at plants.
It is known that phosphorus next to nitrogen and plays a fundamental role in large number or enzymatic reactions that depend on phosphorylation. Hence, phosphorus stimulates early growth, strong root formation, nodulation, and fruit setting, hostens maturity and promotes seed and 
protein yield of legumes (Marschner 1998). In this connection, El-Koumy et al. (1993) found that the addition of phosphate fertilizers increased the dry matter yield of clover tops in the following order AbouZabaal triplephosphate (Abou-Zabaalsuperphosphate > Kafr El-Zait superphosphate.

Potassium influences crop production by enhancing growth and synthetic processes. It is highly important in raising the disease resistance of many crop species. Abou Hussien (2001), reported that the dry mattes yield of wheat plants increased significantly by $\mathrm{K}$-fertilization and this increase was more pronounced for the plants fertilized by $\mathrm{K}_{2} \mathrm{O}$ as compared to those fertilized by $\mathrm{KCl}$.

Maize is one of the most important grain crops grown in Egypt. It plays a fundamental role in human and animal feeding. So the main target of the current investigation is to study the effect of FYM and different sources of $\mathrm{P}$ and $\mathrm{K}$ on some macronutrients in soil and plant.

\section{MATERIALS AND METHODS}

Two surface soil samples $(0-30 \mathrm{~cm})$ were collected from two locations a) Alluvial soil from experimental farm of the Faculty of Agric., Menofiya university, Shibin El-Kom. B) Calcareous soil from Nubaria farm, Beheira Governorate, air dried, and ground to pass through a $2 \mathrm{~mm}$ sieve.

Some physical and chemical properties of these soils were determined and recorded in Table (1).

\section{Treatments and experimental design.}

Polyethylene pots of $15 \mathrm{~cm}$ in diameter and $17 \mathrm{~cm}$ in depth were used and devided into two main groups. Complete randomized blocks design was employed in this study with three replicates. Two $\mathrm{Kg}$ of alluvial and calcareous soils were placed in each pot of the first and second pot groups respectively.

Each pot was fertilized with ammonium nitrate $(33.5 \% \mathrm{~N})$ at $0.6 \mathrm{~g} \mathrm{NH}_{4} \mathrm{NO}_{3} /$ pot as a solution after thinning of plants. Each pot was planted with five seeds of Maize (Zea mays L.) and irrigated with tap water at $60 \%$ of water holding capacity of each soil. After 14 days from planting the plants were thinned to three plants for each pot. Each main group was devided into three sub groups.

FYM was added at rates 0,1 and $2 \%$ of the used soil (Farmyard manur OM $28.2 \%$, $1.25 \% \mathrm{~N}, \mathrm{C} / \mathrm{N}$ ratio $14.6,0.52 \% \mathrm{P}, 1.3 \% \mathrm{~K}$, 90 ppm Zn, 532 ppm Fe, 50 ppm Cu and $115 \mathrm{ppm} \mathrm{Mn}$ ). Phosphorus was added at 0 , 15 and 30 ppm $\mathrm{P}_{2} \mathrm{O}_{5}$ of superphosphate (S.P) and triplephosphate (T.P). All phosphatic fertilizers and $\mathrm{OM}$ treatments were added before the cultivation.

Potassium was added at 0,24 and 48 ppm $\mathrm{K}_{2} \mathrm{O}$ of $\mathrm{K}_{2} \mathrm{SO}_{4}$ and $\mathrm{KCl}$.

Potassium was added after 15 days from planting. The plants were harvested after 45 days from planting and dried at $70^{\circ} \mathrm{C}$ until its weight became constant weighted, ground and kept for chemical analysis. Dry weight of the samples was recorded and statical analyzed, according to Steel and Torri (1980).

\section{Plant analysis}

Plant samples were digested with concentrated $\mathrm{H}_{2} \mathrm{SO}_{4}$ and $\mathrm{H}_{2} \mathrm{O}_{2}$ (cottenie, 1980).

Phosphorus, nitrogen and potassium were determined according to Jackson (1973).

\section{Soil analysis}

Some physical and chemical properties of these soils were determined as follows :

1. Mechanical analysis was performed according to the pipette method (Piper, 1950).

2. Total $\mathrm{CaCO}_{3}$ was determined volumetrically by means of collin's calcimeter (Black, 1965).

3. Soil $\mathrm{pH}$ was determined in soil suspension ( $1: 2.5$, soil : water ratio) according to Richards (1954).

4. Total soluble salts as well as soluble cations and anions were measured in soil extraction (1:5, soil : water) according to Jackson (1958). 


\begin{tabular}{|c|c|c|c|c|}
\hline \multirow{2}{*}{ 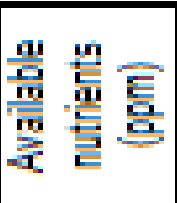 } & \multirow{2}{*}{ 올 } & \multirow[t]{2}{*}{$x$} & \multirow{2}{*}{$\begin{array}{l}d \\
8 \\
8 \\
5\end{array}$} & \multirow[t]{2}{*}{8} \\
\hline & & & & \\
\hline \multicolumn{3}{|r|}{ "혈을 틈 } & 8 & 8 \\
\hline \multirow{5}{*}{$\begin{array}{l}\overline{\mathbf{5}} \\
\mathbf{3} \\
\mathbf{3} \\
\mathbf{3}\end{array}$} & \multirow{4}{*}{ 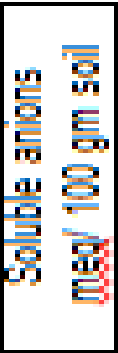 } & 8 & ga & 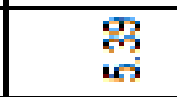 \\
\hline & & 3 & 5 & 9 \\
\hline & & 8 & 8 & $\frac{9}{8}$ \\
\hline & & 8 & $"$ & $"$ \\
\hline & \multirow{4}{*}{ 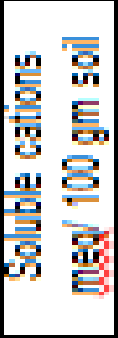 } & 2 & $\begin{array}{l}48 \\
8\end{array}$ & 4 \\
\hline \multirow{3}{*}{$\begin{array}{l}\frac{.1}{5} \\
\frac{2}{9} \\
\overline{9}\end{array}$} & & m & 8 & 8 \\
\hline & & 몸 & 8 & 8 \\
\hline & & 8 & 8 & $\because$ \\
\hline \multicolumn{3}{|r|}{ 운 톡 } & 昰 & 한 \\
\hline \multicolumn{3}{|c|}{  } & 8 & 焉 \\
\hline \multicolumn{3}{|c|}{$8 \geqslant$} & $\frac{16}{5 i}$ & 5 \\
\hline \multicolumn{3}{|r|}{$\frac{3}{6}$} & 5 & $\begin{array}{l}7 \\
0\end{array}$ \\
\hline \multicolumn{3}{|r|}{ 总営 } & $\frac{\mathrm{m}}{\mathrm{m}}$ & 흘름들 \\
\hline \multirow{3}{*}{ 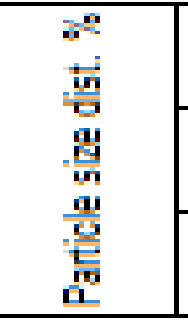 } & & $\frac{\text { 蒠 }}{3}$ & 5 & 9 \\
\hline & & 常 & 8 & 8 \\
\hline & & 몽 & 홍 & ? \\
\hline \multicolumn{3}{|c|}{ 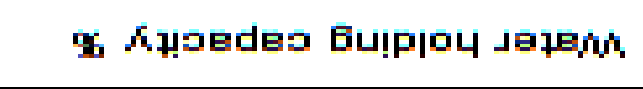 } & 8 & 古 \\
\hline \multicolumn{3}{|c|}{ e|dwes l!og } & 高 & $\begin{array}{l}\frac{3}{3} \\
\frac{3}{3} \\
3\end{array}$ \\
\hline
\end{tabular}


5. Organic matter was determined according to walkley and Black method (Jackson, 1958).

6. Cation exchange capacity was measured by sodium acetate method as described by Richards (1954).

7. Available phosphorus and potassium were determined according to Jackson (1958).

\section{RESULTS AND DISCUSSION Effect of farmyard manure on dry matter yield of corn plants}

Data in Table (2) showed the effect of Farmyard manure (FYM) on dry matter yield. The addition of FYM at rates 1 and $2 \%$ to the soil significantly caused an increases in dry matter yield compared with the control plants. These increases may be attributed to role of organic matter which improve the physical, chemical and biologtcal properties of soil. These double-fold results are in agreement with those obtained by ElKoumey (1998) and El-Shafie (1999).

Data in Table (2) revealed that the dry matter yield of corn plants was significantly affected by soil type. The highest mean value of dry matter yield was found in alluvial soil while the lowest one obtained in calcareous soil. These results may be due to the improvement of soil condition for plant growth on alluvial soil compared with calcareous one. The most beneficial effect of FYM could be explained on bases that they encouraged the formation and stabilization of soil aggregates, consequently susceptibility of soil to crusting sharbly decreased, hence seed germination increased. These results are in agreement with those obtained by Awad (2001). Farmyard manure significantly enhanced hydraulic conductivity in the clay and calcareous soils through their effect on improving aggregation and macro-pores. Also application of FYM decreased soil reaction "pH" values and increased organic matter content.

\section{Effect of different sources of $P$ on dry matter yield}

Data presented in Table (2) showed that phosphatic fertilizers application increased dry matter weights of corn plants grown in both alluvial and calcareous soils compared with the control plants, and the relationship between the obtained dry matter yield and the applied levels of both phosphatic fertilizers were positive. These results may be attributed to the important role of phosphorus on the roots growth which increase nutrients uptake and, also to phosphorus role in plant metabolism, which increase absorption leading to increase dry weight (Marschner, 1998). These results are in agreements with those obtained by Mersal (1996).

The same date revealed that the dry matter values of corn plants occurred induced with triplephosphate additions were more than those with superphosphate at the same levels of application in alluvial soil. These increases are parallel to phosphorus availability in the studied fertilizers. This finding are in agreement with those obtained by El-Koumey et al. (1993).

Also, the results indicated that the values of dry matter with superphosphate additions were more than with triplephosphate additions at the same levels of applications for plants grown on calcareous soil.

This difference may be due to the different chemical formula of the fertilizers where, supperphosphate contains higher calcium and less phosphorus percentage than the triplephosphate. Calcium keeps phosphorus in available form to plants as mono or di-calcium phosphate, which still provides plants with phosphorus and calcium.

In addition calcium helps in preventing amorphus silica and alumina to mineralize phosphate (El-Attar et al., 1986).

Ibrahim (2001) revealed that superphosphate produced more dry matter than triplephosphate with plant, leaves, stem and root. 
Table (2): Effect of farmyard manure, phosphate and potassium fertilizer on the dry matter yield of corn plants.

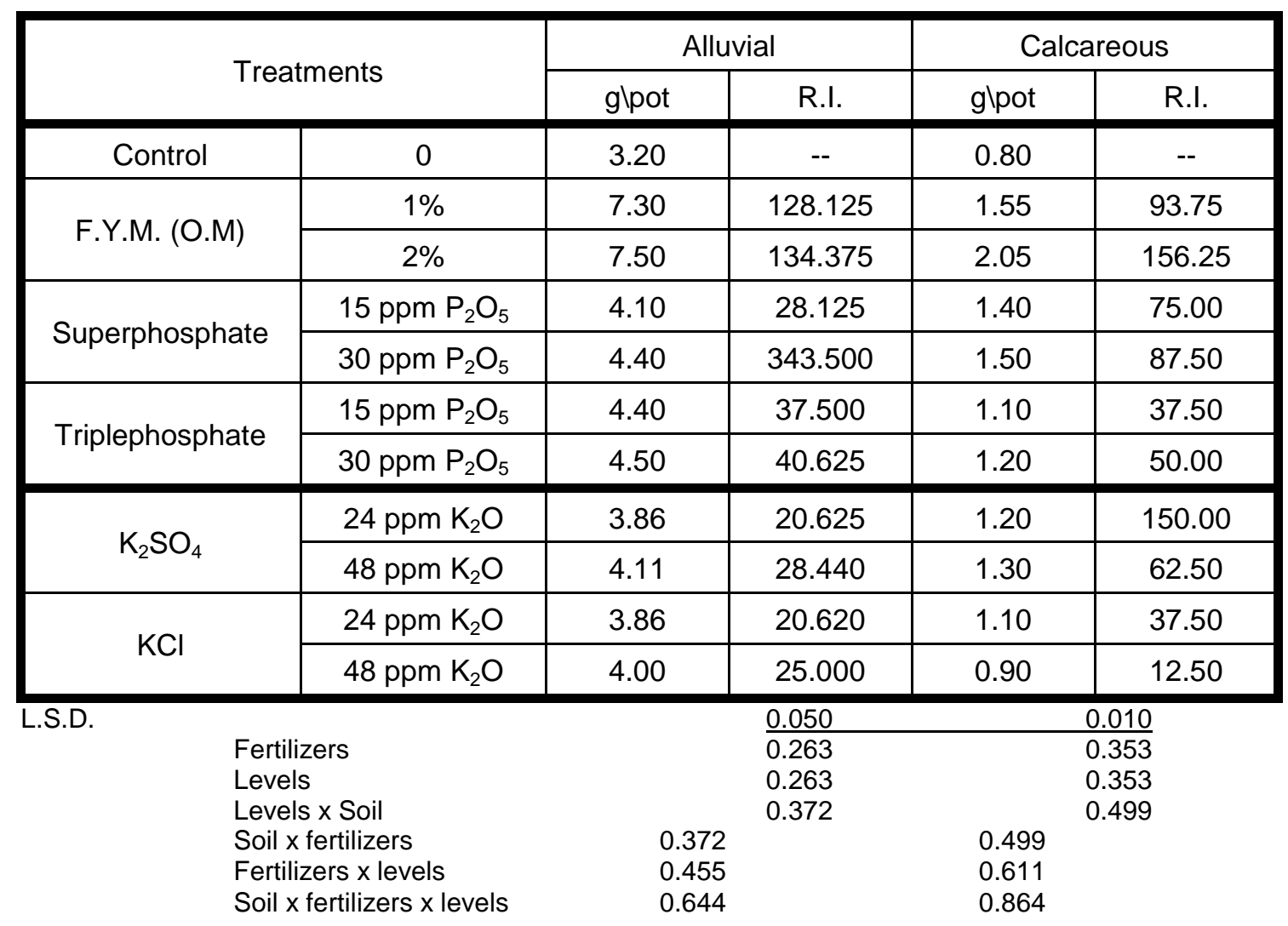

In general, the dry matter yield of corn plants was higher for plants grown on alluvial soil than those grown on calcareous one. These results are attributed to the effect of high exchange able capacity of alluvial soil and its ability to release nutrients during different stages of plant growth and had a beneficial physical, chemical and biological properties. These results are in agreement with those obtained by Khalil (2000).

\section{Effect of different sources of $\mathrm{K}$ on dry matter yield}

Data in Table (2) showed that the dry matter yield of corn plants treated with potassium sulphate were in general more than that with potassium chloride at the same levels of application in both used soils.

The high efficiency of $\mathrm{K}_{2} \mathrm{SO}_{4}$ compared with $\mathrm{KCl}$, may be attributed to its contain of sulphur (S) $18 \%$ which consider one of the essential plant nutrients and plays a major role in plant growth and improvement of physical and chemical properties of sandy and calcareous soils (El-Masry, 1995).

The response of corn growth grown on calcareous soil, was more pronounced with $\mathrm{K}$ application in an increasing order than that for alluvial soil compared to the control plants.

These results are confirmed with those obtained by Abou Hussien (2001) and Haggag and El-Kholy (1998).

\section{Effect of (FYM) on nitrogen content}

Data presented in Table (3) showed a positive relationship between FYM application and $\mathrm{N}$-content. This may be due to relatively high availability of nitrogen in the added FYM its uptake by plants. 
El-Koumey, et al.,

Consequently, it may help to increase the respiration rate metabolism and growth of plants, causing the plant to require more nutrients from soil and fertilizers. These results are in agrrement with those obtained by El-Koumey (1998) and Awad (2001).

\section{Effect of different sources of $P$ on nitrogen :}

Data presented in Table (3) revealed that superphosphate and triplephosphate applications at different levels under study increased $\mathrm{N}$ concentration and its uptake by corn plants as compared with untreated plants. This result may be due to the biological effect of $P$ on plant metabolism and increase nitrogen fixation by bacteria. In this connection, El-Koumey et al. (1993) who found that increasing $P$ increased $\mathrm{N}$ uptake by different plants.

The same data Table (3) also revealed that $\mathrm{N}$ uptake was markedly increased by phosphorus additions for corn plants grown on alluvial and calcareous soils. In general, the amount of $\mathrm{N}$ uptake was obviously higher for plants grown on alluvial soil than those on calcareous one. The raising of application rate of phosphate fertilizers raised the nitrogen uptake than control. These results are in agreement with those obtained by Mersal (1996)

Table (3): Effect of different fertilizers on nitrogen content of corn plants.

\begin{tabular}{|c|c|c|c|c|c|c|c|}
\hline \multirow{2}{*}{ Treatements } & \multirow[t]{2}{*}{ Soil } & \multicolumn{3}{|c|}{ Alluvial } & \multicolumn{3}{|c|}{ Calcareous } \\
\hline & & \multirow{2}{*}{ 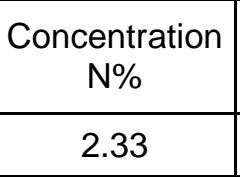 } & \multirow{2}{*}{$\begin{array}{l}\begin{array}{l}\text { Uptake } \\
\text { Mglpot }\end{array} \\
74.560\end{array}$} & \multirow{2}{*}{$\begin{array}{c}\text { R.I. } \\
\text { Uptake } \\
--\end{array}$} & \multirow{2}{*}{$\begin{array}{c}\begin{array}{c}\text { Concentration } \\
\mathrm{N} \%\end{array} \\
1.07 \\
\end{array}$} & \multirow{2}{*}{$\begin{array}{c}\text { Uptake } \\
\text { Mglpot } \\
8.560\end{array}$} & \multirow{2}{*}{$\begin{array}{c}\text { R.I. } \\
\text { Uptake } \\
--\end{array}$} \\
\hline Control & & & & & & & \\
\hline \multirow{2}{*}{ F.Y.M. (O.M) } & $1 \%$ & 2.55 & 186.150 & 149.66 & 1.27 & 19.685 & 129.96 \\
\hline & $2 \%$ & 2.64 & 198.000 & 165.56 & 1.29 & 26.445 & 208.94 \\
\hline \multirow{2}{*}{ Superphosphate } & \begin{tabular}{|l|}
15 \\
ppm \\
$\mathrm{P}_{2} \mathrm{O}_{5}$ \\
\end{tabular} & 2.45 & 100.450 & 34.72 & 1.12 & 15.680 & 83.18 \\
\hline & \begin{tabular}{|l|}
30 \\
$\mathrm{ppm}$ \\
$\mathrm{P}_{2} \mathrm{O}_{5}$ \\
\end{tabular} & 2.58 & 113.520 & 52.25 & 1.18 & 17.700 & 106.78 \\
\hline \multirow{2}{*}{ Triplephosphate } & \begin{tabular}{|l|}
15 \\
$\mathrm{ppm}$ \\
$\mathrm{P}_{2} \mathrm{O}_{5}$ \\
\end{tabular} & 2.57 & 113.080 & 51.66 & 1.22 & 13.420 & 56.78 \\
\hline & \begin{tabular}{|l|}
30 \\
$\mathrm{ppm}$ \\
$\mathrm{P}_{2} \mathrm{O}_{5}$ \\
\end{tabular} & 2.70 & 121.500 & 62.96 & 1.46 & 17.520 & 104.67 \\
\hline \multirow{2}{*}{$\mathrm{K}_{2} \mathrm{SO}_{4}$} & \begin{tabular}{|l|}
24 \\
$\mathrm{ppm}$ \\
$\mathrm{K}_{2} \mathrm{O}$ \\
\end{tabular} & 2.58 & 99.590 & 33.57 & 1.26 & 15.120 & 76.63 \\
\hline & \begin{tabular}{|l|}
48 \\
ppm \\
$\mathrm{K}_{2} \mathrm{O}$ \\
\end{tabular} & 2.71 & 111.380 & 49.38 & 1.31 & 17.030 & 98.95 \\
\hline \multirow{2}{*}{$\mathrm{KCl}$} & \begin{tabular}{|l|}
24 \\
$\mathrm{ppm}$ \\
$\mathrm{K}_{2} \mathrm{O}$ \\
\end{tabular} & 2.57 & 99.200 & 33.05 & 1.29 & 14.190 & 65.77 \\
\hline & $\begin{array}{l}48 \\
\mathrm{ppm} \\
\mathrm{K}_{2} \mathrm{O}\end{array}$ & 2.69 & 107.600 & 44.31 & 1.56 & 14.040 & 64.02 \\
\hline
\end{tabular}




\section{Effect of different sources of $\mathrm{K}$ on nitrogen content :}

Data in Table (3) show that Kapplications at diferent levels under study increased $N$ content by corn plants compared with control. These results may be due to the effect of $K$ on plant growth. These results are in agreement with those obtained by Sobh et al. (2000) and Abou Hussien (2001).

\section{Effect of FYM on phosphorus content :}

Data in Table (4) show that the application of FYM increased P-content in corn plants as compared with untreated plants. This increases in $\mathrm{P}$ content may be attributed to the influence of FYM on the release of $P$ and other elements. The results can be explained by the fact that organic matter plays an important role in improving physical, chemical and biological properties of soil. These results were in accordance with results obtained by El-Fiki (1994) and Awad (2001). The same data in Table (4) showed that $P$ uptake by corn plants grown on alluvial soil was higher than those grown on calcareous soil. This may be due to the ability of organic matter in rendering soil nutrients more available and chelation of these elements by humic substances.

Table (4): Effect of different fertilizers on phosphorus content of corn plants.

\begin{tabular}{|c|c|c|c|c|c|c|c|}
\hline \multirow{2}{*}{ Treatements } & \multirow{2}{*}{ Soil } & \multicolumn{3}{|c|}{ Alluvial } & \multicolumn{3}{|c|}{ Calcareous } \\
\hline & & $\begin{array}{c}\text { Concentration } \\
\text { P\% }\end{array}$ & $\begin{array}{l}\text { Uptake } \\
\text { Mglpot }\end{array}$ & $\begin{array}{c}\text { R.I. } \\
\text { Uptake }\end{array}$ & $\begin{array}{c}\text { Concentration } \\
\text { P\% }\end{array}$ & $\begin{array}{l}\text { Uptake } \\
\text { Mglpot }\end{array}$ & $\begin{array}{l}\text { R.I. } \\
\text { Uptake }\end{array}$ \\
\hline Control & & 0.274 & 8.770 & -- & 0.183 & 1.46 & -- \\
\hline \multirow{2}{*}{ F.Y.M. (O.M) } & $1 \%$ & 0.445 & 32.485 & 270.41 & 0.270 & 4.185 & 186.64 \\
\hline & $2 \%$ & 0.533 & 39.975 & 355.82 & 0.309 & 6.33 & 333.56 \\
\hline \multirow{2}{*}{ Superphosphate } & \begin{tabular}{|l}
15 \\
$\mathrm{ppm}$ \\
$\mathrm{P}_{2} \mathrm{O}_{5}$ \\
\end{tabular} & 0.301 & 12.340 & 40.72 & 0.212 & 2.97 & 103.42 \\
\hline & \begin{tabular}{|l|}
30 \\
$\mathrm{ppm}$ \\
$\mathrm{P}_{2} \mathrm{O}_{5}$ \\
\end{tabular} & 0.322 & 14.170 & 61.57 & 0.236 & 3.54 & 142.47 \\
\hline \multirow{2}{*}{ Triplephosphate } & \begin{tabular}{|l}
15 \\
ppm \\
$\mathrm{P}_{2} \mathrm{O}_{5}$ \\
\end{tabular} & 0.345 & 15.180 & 73.09 & 0.232 & 2.55 & 74.66 \\
\hline & \begin{tabular}{|l|}
30 \\
$\mathrm{ppm}$ \\
$\mathrm{P}_{2} \mathrm{O}_{5}$ \\
\end{tabular} & 0.345 & 15.525 & 77.02 & 0.256 & 3.07 & 110.41 \\
\hline \multirow{2}{*}{$\mathrm{K}_{2} \mathrm{SO}_{4}$} & \begin{tabular}{|l|}
24 \\
$\mathrm{ppm}$ \\
$\mathrm{K}_{2} \mathrm{O}$ \\
\end{tabular} & 0.287 & 11.080 & 26.34 & 0.209 & 2.51 & 71.92 \\
\hline & $\begin{array}{l}48 \\
\mathrm{ppm} \\
\mathrm{K}_{2} \mathrm{O} \\
\end{array}$ & 0.295 & 12.120 & 38.20 & 0.200 & 2.60 & 78.08 \\
\hline \multirow{2}{*}{$\mathrm{KCl}$} & \begin{tabular}{|l|}
24 \\
$\mathrm{ppm}$ \\
$\mathrm{K}_{2} \mathrm{O}$ \\
\end{tabular} & 0.285 & 11.000 & 25.43 & 0.190 & 2.09 & 43.15 \\
\hline & \begin{tabular}{|l|}
48 \\
$\mathrm{ppm}$ \\
$\mathrm{K}_{2} \mathrm{O}$
\end{tabular} & 0.281 & 11.240 & 28.16 & 0.246 & 2.21 & 51.37 \\
\hline
\end{tabular}




\section{Effect of different sources of $P$ on phosphorus content}

Data recorded in Table (4) showed that both $\mathrm{P}$ uptake by corn plants increased with increasing $P$ application levels from 0 to 30 ppm $\mathrm{P}_{2} \mathrm{O}_{5}$ of the two phospherous fertilizers used.

These results can be attributed to the fact that phosphorus fertilizer is often more available for plant than the native soil $P$. These results are in agreement with results obtained by El-Sharawy et al (1994).

Data in Table (4) showed also that the absolute values of $P$ uptake by corn plants grown on alluvial soil fertilized with triplephosphate were more than those obtained by plants treated with superphosphate at all application levels of $P$. These results are in good agreements with those obtained by El-Koumey et al. (1993).

The same Data also showed that $P$ uptake from the applied superphosphate was higher than that by triplephosphate in plants grown on calcareous soil. This results may be due to the triplephosphate in calcareous soil, which precipitated faster than superphosphate. These resultes are in harmony with findings of Ibrahim (2001).

\section{Effecet of diferent sources of $\mathrm{K}$ on phosphorus content}

Data presented in Table (4) showed that the additions of $K$ fertilizers increased $P$ content in corn plants. Increases in P-uptake by corn plants as a results of $\mathrm{K}$ additions may be due to the role of $\mathrm{K}$ in plant as macronutrient. These results are in harmony with the findings of Mallarino et al. (1999).

Data in Table (4) also showed that the absolute values of $\mathrm{P}$ - uptake by corn plants when applied with $\mathrm{K}_{2} \mathrm{SO}_{4}$ were more than those obtained by plants treated with $\mathrm{KCl}$ at all application levels of $\mathrm{K}$. These results are in good agreement with those obtained by El-Kabbany (1999).

\section{Effect of FYM on potassium content :}

Data presented in Table (5) showed that FYM application caused marked increases in K-content of corn plants as compared with untreated plants.

Also, increasing FYM application from 1 to $2 \%$ increased K- uptake by corn plants grown on both alluvial and calcareous soils. This may be due to the effect of organic residues on increasing available potassium and other elements in the soil (AbouHussien, 1997, El-Koumey, 1998 and Awad, 2001).

\section{Effect of differed sources of $P$ on potassium content:}

Data presented in Table (5) showed that $\mathrm{K}$ uptake by corn plants grown on both alluvial and calcareous soils increased with increasing $\mathrm{P}$ application levels from 0 to 30 ppm $\mathrm{P}_{2} \mathrm{O}_{5}$ of the two used phosphorus sources. These results are in agreement with those obtained by Mersal (1996).

\section{Effect of different sources of $K$ on potassium uptake:}

Data in Table (5) showed that the applications of potassium sulphate and potassium chloride at different levels under study increased of $\mathrm{K}$ content by corn plants as compared with untreated plants. This result may be attributed to enhace the availability of $\mathrm{K}$ as a result of $\mathrm{K}$ fertilizer addition.

Data in Table (5) showed also that the increases of K-uptake resulted from potassium sulphate application was higher than that obtained with potassium chloride.

These results are in agreement with those obtained by Moussa (2000) and Abou Hussien (2001).

\section{Effect of FYM on the availability of some macronutrients ( $P$ and $K$ )}

Data in Tables $(6,7)$ showed that the application of FYM increased the availability of $\mathrm{P}$ and $\mathrm{K}$ in soils. It may be due to richness of organic fertilizers (FYM) with organic 
carbon, total $\mathrm{N}$, available $\mathrm{N}, \mathrm{P}, \mathrm{K}$, and their higher C.E.C. rather than effect of FYM on soil $\mathrm{pH}$. These results are in agreement with those obtained by Badran et al. (2000).

\section{Effect of different sources of $P$ on the availability of some macro nutrients ( $P$ and $K$ )}

Data in Tables (6 and 7) showed that, the application of phosphate fertilizers increased available $P$ and slightly increased available $K$ in the used soils. The obtained data showed that the available $\mathrm{P}$ and $\mathrm{K}$ were increased by increasing the rate of $P$ application either in the superphosphate or in the triplephosphate.

Data in Table (6) showed that the application of triplephosphate increased the available phosphorus in alluvial soil than the application of superphosphate. This seems to be in relation to different chemical composition and properties of the used fertilizers.

These results are in agreement with those obtained by El-Koumey et al. (1993).

Data in the same Table (6) revealed that, the application of superphosphate increased the available phosphorus in calcareous soil, than the application of triplephosphate. This may be due to the different chemical formula of the two fertilizers where superphosphate contains higher calcium and less phosphorus percentage than the triplephosphate.

Table (5): Effect of different fertilizers on potassium content of corn plants.

\begin{tabular}{|c|c|c|c|c|c|c|c|}
\hline \multirow{2}{*}{ Treatements } & \multirow[t]{2}{*}{ Soil } & \multicolumn{3}{|c|}{ Alluvial } & \multicolumn{3}{|c|}{ Calcareous } \\
\hline & & \multirow{2}{*}{\begin{tabular}{|c|}
$\begin{array}{c}\text { Concentration } \\
\mathrm{K} \%\end{array}$ \\
1.33 \\
\end{tabular}} & \multirow{2}{*}{$\begin{array}{l}\text { Uptake } \\
\text { Mglpot } \\
42.660 \\
\end{array}$} & \multirow{2}{*}{$\begin{array}{c}\text { R.I. } \\
\text { Uptake } \\
--\end{array}$} & \multirow{2}{*}{\begin{tabular}{|c|}
$\begin{array}{c}\text { Concentration } \\
\mathrm{K} \%\end{array}$ \\
0.630 \\
\end{tabular}} & \multirow{2}{*}{$\begin{array}{c}\text { Uptake } \\
\text { Mglpot } \\
5.040 \\
\end{array}$} & \multirow{2}{*}{$\begin{array}{c}\text { R.I. } \\
\text { Uptake } \\
-- \\
\end{array}$} \\
\hline Control & & & & & & & \\
\hline \multirow{2}{*}{ F.Y.M. (O.M) } & $1 \%$ & 1.83 & 133.590 & 213.15 & 1.030 & 15.965 & 216.77 \\
\hline & $2 \%$ & 2.05 & 153.750 & 260.41 & 1.060 & 21.730 & 331.15 \\
\hline \multirow{2}{*}{ Superphosphate } & \begin{tabular}{|l}
15 \\
$\mathrm{ppm}$ \\
$\mathrm{P}_{2} \mathrm{O}_{5}$ \\
\end{tabular} & 1.43 & 58.630 & 37.44 & 0.819 & 11.470 & 127.58 \\
\hline & \begin{tabular}{|l|}
30 \\
$\mathrm{ppm}$ \\
$\mathrm{P}_{2} \mathrm{O}_{5}$ \\
\end{tabular} & 1.46 & 64.240 & 50.59 & 0.810 & 12.150 & 141.07 \\
\hline \multirow{2}{*}{ Triplephosphate } & $\begin{array}{l}15 \\
\mathrm{ppm} \\
\mathrm{P}_{2} \mathrm{O}_{5}\end{array}$ & 1.46 & 64.240 & 50.59 & 0.850 & 9.350 & 85.52 \\
\hline & \begin{tabular}{|l|}
30 \\
$\mathrm{ppm}$ \\
$\mathrm{P}_{2} \mathrm{O}_{5}$ \\
\end{tabular} & 1.57 & 70.650 & 65.61 & 0.940 & 11.280 & 123.81 \\
\hline \multirow{2}{*}{$\mathrm{K}_{2} \mathrm{SO}_{4}$} & \begin{tabular}{|l|}
24 \\
$\mathrm{ppm}$ \\
$\mathrm{K}_{2} \mathrm{O}$ \\
\end{tabular} & 1,64 & 63.300 & 48.38 & 0.710 & 8.520 & 69.05 \\
\hline & $\begin{array}{l}48 \\
\mathrm{ppm} \\
\mathrm{K}_{2} \mathrm{O}\end{array}$ & 1.66 & 68.230 & 59.94 & 0.720 & 9.360 & 85.71 \\
\hline \multirow{2}{*}{$\mathrm{KCl}$} & $\begin{array}{l}24 \\
\mathrm{ppm} \\
\mathrm{K}_{2} \mathrm{O} \\
\end{array}$ & 1.61 & 62.150 & 45.69 & 0.700 & 7.700 & 52.78 \\
\hline & \begin{tabular}{|l|}
48 \\
$\mathrm{ppm}$ \\
$\mathrm{K}_{2} \mathrm{O}$
\end{tabular} & 1,65 & 66.000 & 54.71 & 0.925 & 8.325 & 65.18 \\
\hline
\end{tabular}


El-Koumey, et al.,

Table (6): Effect of different fertilizers on available $P$ in used soils after plant harvest.

\begin{tabular}{|c|c|c|c|c|c|}
\hline \multirow{2}{*}{\multicolumn{2}{|c|}{ Treatements }} & \multicolumn{2}{|c|}{ Alluvial } & \multicolumn{2}{|c|}{ Calcareous } \\
\hline & & \multirow{2}{*}{\begin{tabular}{|c|}
$\begin{array}{c}\text { Concentration } \\
(\mathrm{ppm})\end{array}$ \\
7.73 \\
\end{tabular}} & \multirow{2}{*}{$\begin{array}{c}\text { R.I. } \\
\text { Change \% } \\
--\end{array}$} & \multirow{2}{*}{$\begin{array}{c}\text { Concentration } \\
(\mathrm{ppm})\end{array}$} & \multirow{2}{*}{$\begin{array}{c}\text { R.I. } \\
\text { Change \% } \\
--\end{array}$} \\
\hline Control & & & & & \\
\hline \multirow{2}{*}{ F.Y.M. (O.M) } & $1 \%$ & 13.90 & 80.10 & 11.86 & 319.00 \\
\hline & $2 \%$ & 22.40 & 190.16 & 20.49 & 624.00 \\
\hline \multirow{2}{*}{ Superphosphate } & $15 \mathrm{ppm} \mathrm{P}_{2} \mathrm{O}_{5}$ & 8.89 & 15.10 & 4.64 & 64.00 \\
\hline & $30 \mathrm{ppm} \mathrm{P}_{2} \mathrm{O}_{5}$ & 10.05 & 30.01 & 5.40 & 91.31 \\
\hline \multirow{2}{*}{ Triplephosphate } & $15 \mathrm{ppm} \mathrm{P}_{2} \mathrm{O}_{5}$ & 9.47 & 22.51 & 3.10 & 9.50 \\
\hline & 30 ppm $\mathrm{P}_{2} \mathrm{O}_{5}$ & 10.63 & 37.52 & 3.87 & 36.65 \\
\hline \multirow{2}{*}{$\mathrm{K}_{2} \mathrm{SO}_{4}$} & 24 ppm $\mathrm{K}_{2} \mathrm{O}$ & 7.27 & -5.95 & 2.83 & 00.00 \\
\hline & 48 ppm $\mathrm{K}_{2} \mathrm{O}$ & 7.27 & -5.95 & 2.83 & 00.00 \\
\hline \multirow{2}{*}{$\mathrm{KCl}$} & 24 ppm $\mathrm{K}_{2} \mathrm{O}$ & 7.27 & -5.95 & 2.83 & 00.00 \\
\hline & 48 ppm $\mathrm{K}_{2} \mathrm{O}$ & 7.27 & -5.95 & 2.83 & 00.00 \\
\hline
\end{tabular}

Table (7): Effect of different fertilizers on available $\mathrm{K}$ in used soils after plant harvest.

\begin{tabular}{|c|c|c|c|c|c|}
\hline \multirow{2}{*}{\multicolumn{2}{|c|}{ Treatements }} & \multicolumn{2}{|c|}{ Alluvial } & \multicolumn{2}{|c|}{ Calcareous } \\
\hline & & \multirow{2}{*}{$\begin{array}{c}\begin{array}{c}\text { Concentration } \\
(\mathrm{ppm})\end{array} \\
454.63\end{array}$} & \multirow{2}{*}{$\begin{array}{c}\text { R.I. } \\
\text { Change \% } \\
--\end{array}$} & \multirow{2}{*}{$\begin{array}{c}\begin{array}{c}\text { Concentration } \\
(p p m)\end{array} \\
253.81\end{array}$} & \multirow{2}{*}{$\begin{array}{c}\text { R.I. } \\
\text { Change \% } \\
--\end{array}$} \\
\hline Control & & & & & \\
\hline \multirow{2}{*}{ F.Y.M. (O.M) } & $1 \%$ & 479.42 & +5.45 & 360.04 & +41.85 \\
\hline & $2 \%$ & 519.30 & +14.22 & 452.73 & +78.37 \\
\hline \multirow{2}{*}{ Superphosphate } & $15 \mathrm{ppm} \mathrm{P}_{2} \mathrm{O}_{5}$ & 461.02 & +1.41 & 257.05 & +1.28 \\
\hline & $30 \mathrm{ppm} \mathrm{P}_{2} \mathrm{O}_{5}$ & 472.13 & +3.85 & 258.61 & +1.89 \\
\hline \multirow{2}{*}{ Triplephosphate } & $15 \mathrm{ppm} \mathrm{P}_{2} \mathrm{O}_{5}$ & 474.90 & +4.46 & 262.39 & +3.38 \\
\hline & 30 ppm $\mathrm{P}_{2} \mathrm{O}_{5}$ & 481.85 & +5.99 & 273.50 & +7.76 \\
\hline \multirow{2}{*}{$\mathrm{K}_{2} \mathrm{SO}_{4}$} & 24 ppm $\mathrm{K}_{2} \mathrm{O}$ & 482.51 & +6.13 & 276.81 & +9.06 \\
\hline & 48 ppm $\mathrm{K}_{2} \mathrm{O}$ & 491.56 & +8.12 & 296.55 & +16.84 \\
\hline \multirow{2}{*}{$\mathrm{KCl}$} & $24 \mathrm{ppm} \mathrm{K} \mathrm{K}_{2} \mathrm{O}$ & 479.76 & +5.73 & 271.56 & +6.99 \\
\hline & $48 \mathrm{ppm} \mathrm{K}_{2} \mathrm{O}$ & 489.91 & +7.76 & 293.20 & +15.52 \\
\hline
\end{tabular}

Calcium Keeps phosphorus in available form to plants as mono-or di-calcium phosphate, which still provides plants with phosphorus and calcium. Also high calcium carbonate in calcareous soil precipitate a large portion of the added phosphorus.

Also, high $\mathrm{pH}$ level of the calcareous soils which tend to be low in organic matter 
and available nitrogen resulted in unavailability of phosphate. Also, it may be due to superphosphate contains gypsum. The gyysum- $\mathrm{CaCO}_{3}$ interaction, the $\mathrm{CaCO}_{3}$ was precipitated on the gypsum particle surfaces, forming a coating layer.

Available $\mathrm{P}$ and $\mathrm{K}$ in alluvial soil were higher than those in calcareous one. This may be attributed to high CEC, high organic matter and high clay content. These results are in agreement with obtained by Khalil (2000).

Data in Table (7) revealed that, the application of triplephosphate increased the available potassium in alluvial and calcareous soils than the application of superphosphate. El-Koumey et al. (1993).

Effect of different sources of $K$ on the availability of macro-nutrients ( $P$ and $K$ ).

Data in Table (7) showed that the application of $\mathrm{K}$ increased the available $\mathrm{K}$ in both used soils and slightly decreased available $P$ in alluvial soil but there is no effect in calcareous soil.

These results are in agreement with AbdEl-Hadi and Ismail (2000).

\section{REFERENCES}

Abd-El-Hadi, A.H. and K.M. Ismial (2000). Potassium use efficiency under modern irrigation system in a sandy soil in Egypt. AFA 6 th International annual conferece. Cairo Egypt.

Abou Hussien, E.A. (2001). Effect of potassium fertilizer on wheat response to iron in sandy soil treated by calcium carbonate. Conference of sustainable Agriculture Development. Fayoum Faculty of Agriculture March pp 292 504.

Abou Hussien, E.A. (1997). Evaluation of humic acids as iron carriers for plant nutrition. Menofiya, J. Agric. Res. 22 (2) : $581-611$.

Awad, M.Y.M. (2001). Effect of some organic compounds on soil properties and plant growth. M.Se. Thesis, Fae. of Agric. Minufiya Univ. Egypt.

Badran, N.M., M.E.A. Khalil and M.A.A. ElHmam (2000). Availability of N, P and K in sandy and clayey soils as affected by the addition of organic materials. Egypt. J. Soil Sci. $40(1-2) .: 265$ - 283.

Black, C.A. (1965). Methods of soil analysis. Am. Soc. Agron., Inc. Pub. Madison, Wisconsin, U.S.A.

Cottenie, A. (1980). Soil and plant testing as basis of fertilizer recommendations. F.A.O. Soils Bull., 38 / 2 Fao, Rome.

Cottenie, A., ML Verloo, L. Kikens, G. Velghe and R. Camerlynch (1982). Analytical proplems and methods in chemical plant and soil analysis. Hand book Ed. A. Cottenie, Gent., Belgium (1982).

El-attar, H.A., H. El-Sheemy, E.M. Elzahaby and I.I. Mahmoud (1986). Phosphate behaviour with some clay minerals, hydroxides and limestone Egypt. J. Soil Sci. 26 (1): 21-32.

El-Fiki, S.F. (1994). Effect of some macro., and micronutrients on yield and its biochemical components of soybean. M.Sc. Thesis, Fac. Agric., Menufiya Univ., Egvpi.

El-Kabbany, E.A.Y. (1999). Effect of forms and levels of potassium fertilizer on yield and chemical composition of potato. J. Agric. Sci. Mansoura Univ., 24 (1): 7039 7048.

El-Koumey, B.Y. (1998). Influence of organic manures alone or combined with $\mathrm{B}$ or $\mathrm{Zn}$ on maize plant. Menofiya J. Agric. Res., 23 (4) : I 129 - 1139.

El-Koumey, B.Y., E.A. Abou-Husien and F.S. El-Shafie (1993). Influence of phosphatic fertilizers on $\mathrm{N}, \mathrm{P}, \mathrm{K}$ and some Heavy Metals in soil and plant;. Zagazig J. Agric. Res., 20 (6) : 2029 2044.

El-Koumey, B.Y., M.R.M. Rabeh and S.W. Barsoom (1993). Effect of organic fertilization and some micro-nutrients on balady mandarin trees 1-growth and 
nutrients content. Zagazig J. Agric. Res. 20 (6): 1995-2013.

El-Masry, A.A.Y. (1995). Effect of some soil amendments on the availability of nutrients to plant. M.Sc. Thesis Fac. of Agric. Al-Azhar Univ. Egypt.

El-Shafei, F.S. (1999). Effect of poudrette, zinc and copper application on corn growth and nutrients uptake in calcareous soils. Menfiya J. Agric. Res. 24 (4): 1429-1439.

El-Sharawy, M.O., I.M. Elwan and E.M. Abd Elmoniem (1994). Response of corn plants to feeding with phosphorus and zinc. Menfiya J. Agric. Res. 19 (1): 765778.

Haggag, M. El-H. and M.H. El-Kholy (1998). Effect of potassium fertilizer forms and rates on yield and Quality of Egyptian clover. J. Agric. Sci. Mansoura Univ., 23 (11): 5189-5196.

Ibrahim, I.I.M. (2001). Soil MglCa ratio in relation to the availability of phosphorus and its translocation in plant. Ph.D. Thesis, Fac. of Agric. Minufiya Univ., Egypt.

Jackson, M.L. (1958). Soil chemical analysis. Constable and Co. Ltd., London.

Jackson, M.L. (1973). Soil chemical analysis, Prentice Hall, Inc., Engle-Wood Cliffs, N.Y.

Khalil, H.M. (2000). Influence of soil properties on plant requirements of phosphorus in some soils of Egypt. M.Sc.
Thesis, Fac. of Agric., Menofiya Univ., Egypt.

Mallarino, Antonio, P.; Bordoli Joes M. and Rogeno Borges (1999). Phosphorus and Potassium placement effect on early growth and nutrients uptake of no-tell corn and relationship with grain yield. Agron. J., 91: 37-45.

Marschner, H. (1998). "Mineral nutrition in higher plants". Academic press, Harcourt. Barace Jovanovisch. Publischer.

Mersal, F.R.I. (1996). Effect of phosphorus and iron fertilization on plant growth on soil varied in alkalinity. M.Sc. Thesis, Fac. of Agric. Menofiya Univ., Egypt.

Moussa, B.I.M. (2000). Response of wheat plants grown in sandy soils to $\mathrm{K}$ and some micronutrients fertilization. Egypt. J. Soil Sci., 40 (4): 481-493.

Piper, C.S. (1950). Soil and palnt analysis. Inter. Sci. Publ., Inc. New York.

Richards, L.A. (1954). Diagnosis and improvement of saline and alkali soils. U.S. Salinity Lab. Staff Agric. Handbook No. 60.

Sobh, M.M., M.W. Abd El-Hanid and M. Gouda (2000). Yield and chemical composition of maize as affected by macronutrients fertilization. Zagazig J. Agric. Res. 27 (1): 159-169.

Steel, R.G.D. and J.H. Torrie (1980). "Principles and procedures of statistics, a biometrical approach. Scond Edit. Mc. Graw-Hill, Co. New York.

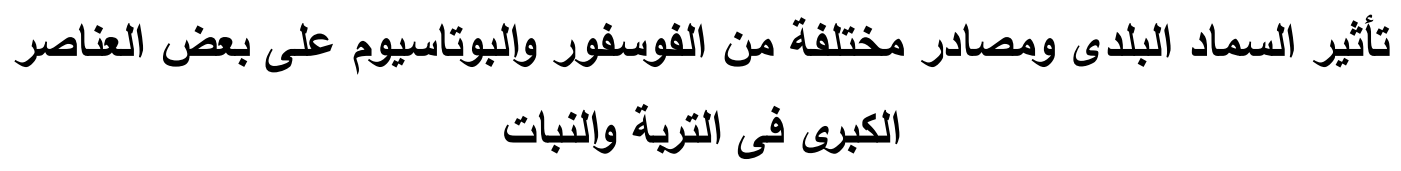




\section{بلر يوسف الكومى(1) ، فاطمة سعد الثافعى(1) ، محمد مصطفى شحاتة(1) ،}

سامية سعد الكلاوى (2)

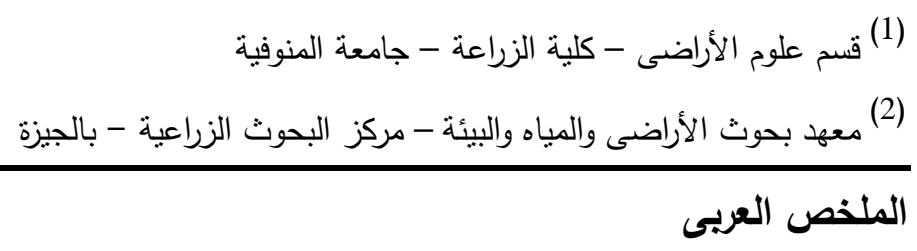

أجريت تجربة أصص بكلية الزراعة جامعة المنوفية لدراسـة تأثير مصـادر ومعدلات مختلفة من الفوسفور

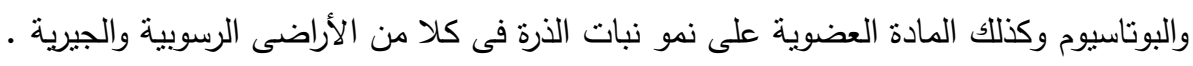

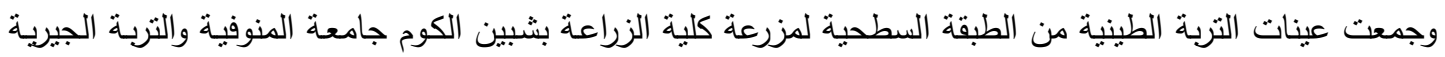

من الطبقة السطحية لمزرعة النوبارية محافظة البحيرة.

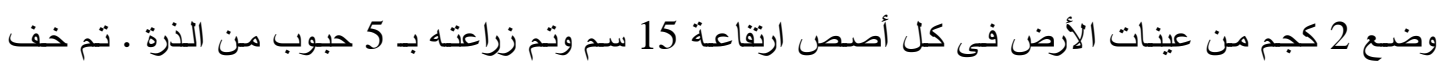

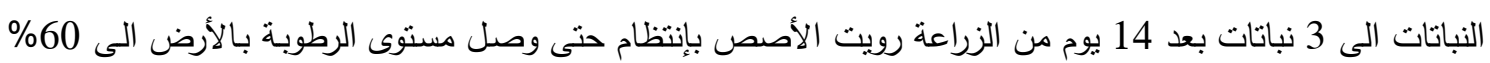

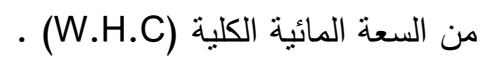

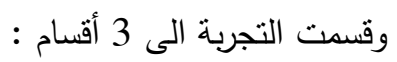

1- القسم الأول لدراسة نأثير المعاملة بمعدلات مختلفة من السماد العضوى (السماد البلاى) (صفر ، 1 ، 2\% من وزن

التربة).

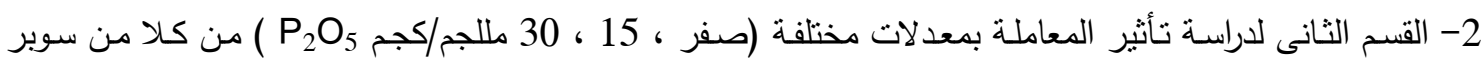

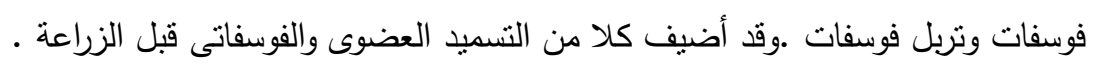

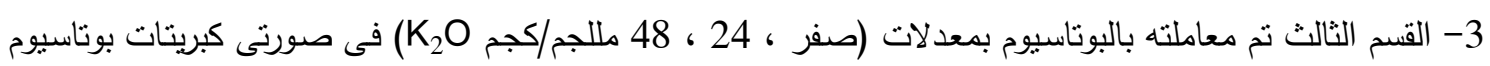

$$
\text { وكلوريد بوتاسيوم · }
$$

تم إضافة أسمدة البوتاسيوم والزنكك والحديد بعد 15 يوم من الزراعة ، حصدت النباتات بعد 45 يوم وجففت فى وري القرن عند 70 م وحسب وزنها الجاف وطحنت ثم تم تحليلها كيميائياً. .

أدت إضافة السماد البلدى بمعدلاته 1 ، 2\% الى كل مل من الأرض الطينية والجيرية الى زيادة معنوية فى المادة

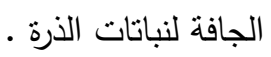

أدث إضافة السماد البلدى الى كل من الأرضين الى زيادة تركيز وامتصاص النيتروجين والفوسفور بواسطة نبات

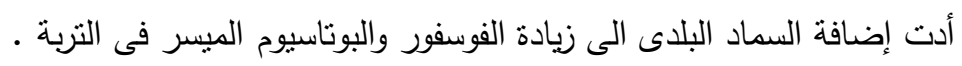

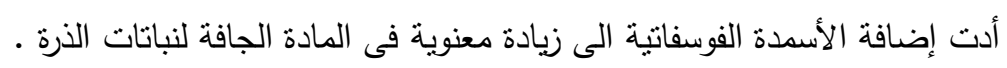

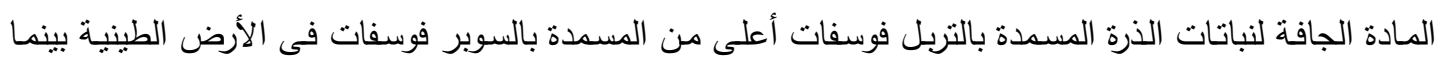

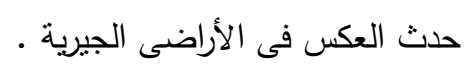

أدت إضافة الأسدة الفوسفانية الى زيادة الفوسفور الميسر وكذلك زيادة طفيفة للبوتاسيوم الميسر فى كل من نوعى 


\section{El-Koumey, et al.,}

أدث إضافة سماد التربل فوسفات الى زيادة الفوسفور الميسر فى الأرض الطينية بدرجة أكثر من السوبر فوسفات

$$
\text { بينما حدث العكس فى الأرض الجيرية . }
$$

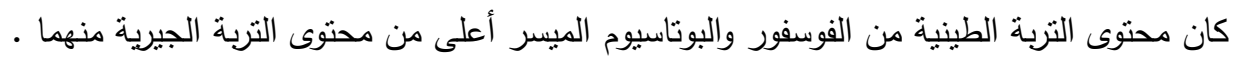

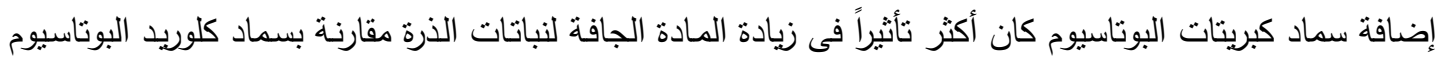

فى كل من التربة الطينية والجيرية .

كانت النباتات النامية فى الأرض الجيرية أكثر استجابة للتسميد البوتاسى من النباتات النامية فى الأراضى الطينية .

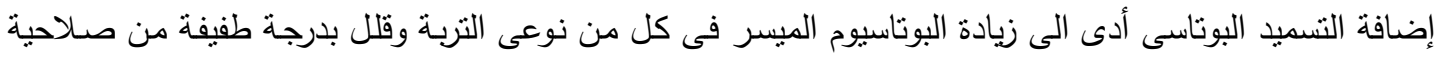

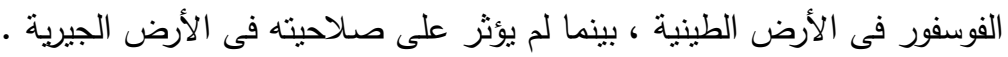




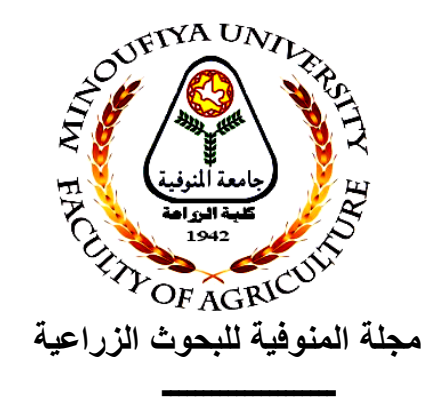

السيد الأستاذ الاكتور/ عميد الكلية

ورئيس تحرير مجلة المنوفية للبحوث الزراعية

\section{تحية طيبة 00 وبعد ،،}

برجاء التفضل بالموافقة على استخراج شيك بمبلغ 305 جنيها فقط ثلاثمائسة وخمسـة

جنيها لا غير قيمة قطع غيـار خاصـة بآلـة التصوير توشيبا العربس موديل 212 E الخاصـة بالمجلة باسم شركة العربى للتجارة والصناعة وذلك من حساب مجلة المنوفية للبحوث الزراعية

وتفضلوا سيادتكم بقبول وافر التحية ،،؛

مدير التحرير

أ.دا/ محمد سمير عراقي عميره 